\title{
Impact of genomics on the field of probiotic research: historical perspectives to modern paradigms
}

\author{
Brant R. Johnson • Todd R. Klaenhammer
}

Received: 22 January 2014 / Accepted: 4 April 2014/Published online: 20 April 2014

(C) The Author(s) 2014. This article is published with open access at Springerlink.com

\begin{abstract}
For thousands of years, humans have safely consumed microorganisms through fermented foods. Many of these bacteria are considered probiotics, which act through diverse mechanisms to confer a health benefit to the host. However, it was not until the availability of whole-genome sequencing and the era of genomics that mechanisms of probiotic efficacy could be discovered. In this review, we explore the history of the probiotic concept and the current standard of integrated genomic techniques to discern the complex, beneficial relationships between probiotic microbes and their hosts.
\end{abstract}

Keywords Probiotic - Lactic acid bacteria . Fermentation · Genomics · Lactobacilli ·

Bifidobacteria
B. R. Johnson · T. R. Klaenhammer ( $\square)$

Department of Microbiology, North Carolina State

University, Raleigh, NC, USA

e-mail: Klaenhammer@ncsu.edu

T. R. Klaenhammer

Department of Food, Bioprocessing, and Nutrition Science, North Carolina State University, Raleigh, NC, USA

\section{Introduction}

History of probiotic bacteria and the probiotic concept

A multitude of autochthonous (naturally occurring) commensal bacterial species inhabit the mucosal surfaces of the gastro-intestinal tract (GIT), as well as those of the nose, mouth and vagina. It has long been held that the consumption of allochthonous (transient) beneficial bacteria, either through food products or supplements, has a positive influence on general health and well-being of the host via commensal interactions with the GIT immune system and resident microbiota. These beneficial microorganisms, known as probiotics, are defined by the World Health Organization as "live microorganisms, which when administered in adequate amounts, confer a health benefit upon the host" (FAO/WHO 2002). Over the past four decades, there has been substantial research in the field of probiotics and, more specifically, into the mechanism of probiotic action within the host. However, the probiotic concept is not novel to the twentieth century and twenty-first centuries.

For millennia, humans have consumed microorganisms via fermented foods, which served to prevent putrefaction as well as increase sensory aspects in the food. Some of the first fermentations were likely the result of serendipitous contaminations in favourable environments resulting in soured milk products such as kefir, leben, koumiss, yogurt and sour cream- 
products that are still consumed worldwide (Hosono 1992). Furthermore, through the continued practice of milk souring along with back slopping techniques, humans inadvertently aided in the domestication of certain microorganisms to diverse food environments over time (Douglas and Klaenhammer 2010). Not only were these products safe to consume, fermented dairy foods were culturally significant, as evidenced by their mention in the Bible and early sacred Hindu texts, as well as therapeutically consumed (Hosono 1992; Bibel 1988; Shortt 1999).

In the late nineteenth century, French biochemist Louis Pasteur premiered significant discoveries leading to a greater scientific understanding of fermentation (Fig. 1). Upon studying wine and beer fermentations, Pasteur demonstrated that fermentation reactions are carried out by microorganisms. Furthermore, he established that the growth of these microbes is not a product of spontaneous generation, as was the prevailing scientific and cultural consensus, but is instead due to biogenesis, which posits that all living things come only from other living things. On the foundation of Pasteur's research, Russian Nobel laureate, Élie Metchnikoff first popularized the concept of probiotics around the turn of the twentieth century. In his book, The Prolongation of Life: Optimistic Studies, Metchnikoff (1907) proposed that putrefaction in the intestines correlated with shortened life expectancy. Reconciling long-held observations involving lactic acid food fermentations with microbial feeding studies in animals and humans, Metchnikoff proposed that lactic acid-producing microorganisms may act as anti-putrefactive agents in the gastrointestinal tract when consumed. In fact, he hypothesized that by transforming the "wild population of the intestine into a cultured population... the pathological symptoms may be removed from old age, and... in all probability, the duration of the life of man may be considerably increased" (Metchnikoff 1907). His theory was bolstered upon observing a higher prevalence of centenarians in Bulgaria, a region known for the consumption of soured milk. Michel Cohendy, a colleague at the Pasteur Institute, provided experimental data to support Metchnikoff's hypothesis. In two feeding trials of human subjects, Cohendy found that the Bulgarian bacillus (now known as Lactobacillus delbrueckii subsp. bulgaricus) was recoverable from faeces; reduced the prevalence of putrefactive toxins; and aided in the treatment of colitis following transplantation to the large intestine (Cohendy 1906a, b). The aforementioned studies on $L$. bulgaricus enthralled the health-conscious society of Europe in the early $20^{\text {th }}$ century and soon the Pasteur Institute of Paris began selling the Lactobacillus under the label of "Le Ferment" (Shortt 1999; Bibel 1988).

Despite the promising observations made by Metchnikoff and colleagues at the genesis of the probiotic concept, there was still meager scientific evidence suggesting any definitive probiotic strains or their purported effector mechanisms. In fact, Leo Rettger and coworkers at Yale University found that $L$. bulgaricus could not survive gastric passage to colonize the small intestine (Rettger 1915). This study called into question which strain(s) may have been

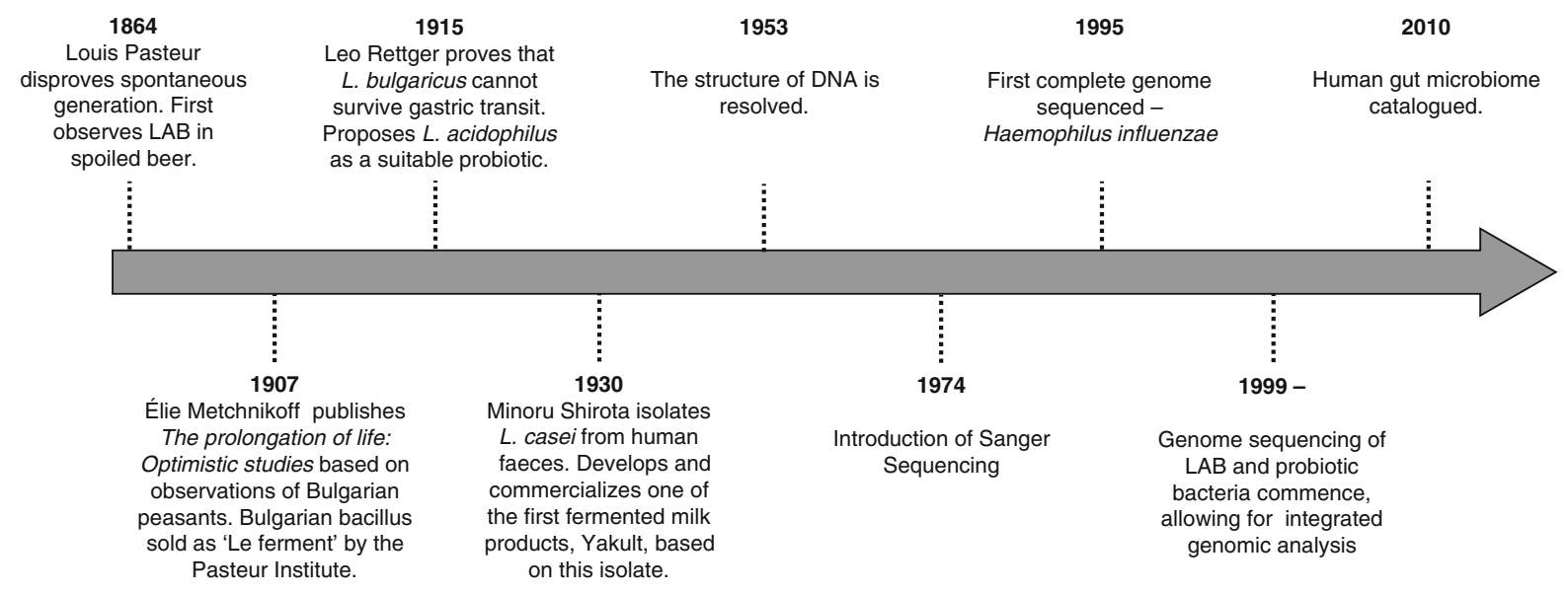

Fig. 1 Seminal milestones contributing to the functional characterization of probiotic lactic acid bacteria 
present in the original therapeutic administration studies performed by Cohendy, and subsequently sold as "Le Ferment." Instead, Lactobacillus acidophilus was touted to be a more suitable candidate for therapeutic applications because of its ability to survive gastric passage and transform the intestinal flora in conditions of lactose and dextrin supplementation (Rettger and Cheplin 1921). It is based on these seminal studies that the foundation of therapeutic treatment with $L$. acidophilus originated. However, even rigorous studies such as these were limited by the techniques and technologies of their time. L. acidophilus could not be distinguished from other aciduric commensal lactobacilli, such as Lactobacillus gasseri, until electrophoretic DNA-DNA hybridization studies on Lactobacillus lactate dehydrogenase enzymes were performed in the 1970s (Gasser 1970; Gasser et al. 1970). Therefore, it is unknown whether the cultures administered during these studies were indeed pure $L$. acidophilus, or mixed culture with $L$. acidophilus, $L$. gasseri and other aciduric lactobacilli.

After examining the burgeoning experimental evidence of probiotic bacteria, a Japanese physician named Minoru Shirota sought to isolate a humanderived strain of Lactobacillus for therapeutic application. And thus, in 1930, Shirota selected a species of Lactobacillus (now known as Lactobacillus casei Shirota) from human faeces that could survive passage through the GIT (Shortt 1999). From this culture, Shirota developed and commercialized one of the first fermented milk products, Yakult (Shortt 1999). Not only was this a major advancement for the commercial dairy industry, but one of the first products to deliver a pure, defined strain-cultured product. Yakult remains a staple product in Japanese, Korean, Australian and European markets. Since then, there has been a massive expansion of the functional food market, especially in fermented dairy products containing probiotic bacteria (Sanders and in't Huis-Veld 1999). In fact, a recent global market analysis on probiotics revealed a $7 \%$ annual growth during the 2012 fiscal year, with a forecast of $\$ 48$ billion in earnings within the next 5 years (Global Industry Analysis Report 2012). Furthermore, probiotics are expanding from functional food markets to pharmaceutical, therapeutic markets. This market increase correlates to the advancements of the scientific and regulatory aspects of probiotic mechanisms and delivery (Foligne et al. 2013). Considering that there are still a great number of scientific questions to explore concerning probiotic activities and interactions in the GIT, there remains a bright future for the field of probiotic research and the market thereof.

\section{Modern use of probiotic bacteria}

Despite the long, storied history of probiotic discovery and therapeutic application, resounding clinical and experimental evidence for the use of probiotic bacteria has only recently come to a head (Table 1). One prominent example is the use of probiotics to treat functional gastrointestinal disorders (FGID). For many FGID, such as irritable bowel syndrome (IBS), there are few pharmacological treatment options due to low efficacy and serious side effects (Shen and Nahas 2009). Furthermore, IBS is quite common and is thought to be caused by changes in the gastrointestinal microbiome (Porter et al. 2011). Recently, a systematic review of successful clinical interventions using probiotics to treat various FGID has been compiled as a reference for clinicians to make evidence-based treatment decisions (Hungin et al. 2013). This systematic analysis reflects a notable caveat that must be made in probiotic research; namely, that probiotic activities are strain-specific (Hungin et al. 2013; Sanders et al. 2013). Because evidence clearly suggests not only the efficacy of probiotic therapy, but also the importance of understanding each strain, the paradigm of probiotic research is rightfully shifting towards understanding the mechanistic action of each specific strain.

Among the most studied species of probiotic bacteria are those from the genera Lactobacillus and Bifidobacterium (Table 2). The genus Lactobacillus is comprised of a diverse clade of Gram-positive, anaerobic/microaerophilic, non-sporulating, low $\mathrm{G}+\mathrm{C}$ content lactic acid bacteria (LAB) belonging to the phylum Firmicutes (Pot et al. 1994). Biochemically, they are strictly fermentative; sugar fermentations result in either the sole production of lactic acid, or the production of lactic acid in conjunction with smaller amounts of carbon dioxide and ethanol/acetic acid (Hammes and Vogel 1995; Pot et al. 1994). Lactobacilli inhabit diverse ecological niches including the GIT of humans and animals, as well as vegetable, plant and dairy food environments. While Lactobacillus species are not dominant members of the colonic microbiotia, many are probiotic because of 
Table 1 Roles and benefits of probiotic bacteria in the GIT

\begin{tabular}{|c|c|}
\hline Probiotic role/benefit & Reference \\
\hline Protection against infection & Corr and O’Neill (2009) \\
\hline $\begin{array}{l}\text { Symptom relief from irritable } \\
\text { bowel syndrome }\end{array}$ & Hungin et al. (2013) \\
\hline $\begin{array}{l}\text { Lactose digestion for lactose- } \\
\text { intolerant individuals }\end{array}$ & $\begin{array}{l}\text { Mattila-Sandholm et al. } \\
\text { (1999) }\end{array}$ \\
\hline Lowered incidence of diarrhea & Leyer et al. (2009) \\
\hline $\begin{array}{l}\text { Lowered risk of antibiotic- } \\
\text { associated diarrhea }\end{array}$ & Gao et al. (2010) \\
\hline $\begin{array}{l}\text { Lowered risk of } C \text {. dificile- } \\
\text { associated diarrhea }\end{array}$ & $\begin{array}{l}\text { Plummer et al. (2004), Gao } \\
\text { et al. (2010) }\end{array}$ \\
\hline Reduction in intestinal bloating & Ringel-Kulka et al. (2011) \\
\hline $\begin{array}{l}\text { Abdominal pain analgesic (via } \\
\mu \text {-opiod and cannabinoid } \\
\text { receptors) }\end{array}$ & Rousseaux et al. (2007) \\
\hline $\begin{array}{l}\text { Lowered levels of cold and } \\
\text { influenza-like symptoms in } \\
\text { children }\end{array}$ & Leyer et al. (2009) \\
\hline Antimicrobial activity & Ryan et al. (2009) \\
\hline $\begin{array}{l}\text { Competitive exclusion of } \\
\text { pathogens }\end{array}$ & Lee et al. (2003) \\
\hline Inhibition of $H$. pylori growth & $\begin{array}{l}\text { Ushiyama et al. (2003); } \\
\text { Fujimura et al. (2012) }\end{array}$ \\
\hline $\begin{array}{l}\text { Reduced incidence of } \\
\text { necrotizing enterocolitis }\end{array}$ & Deshpande et al. (2010) \\
\hline $\begin{array}{l}\text { Prevention of upper respiratory } \\
\text { infections }\end{array}$ & Hao et al. (2011) \\
\hline Immune tolerance & van Baarlen et al. (2009) \\
\hline $\begin{array}{l}\text { Reduction in colorectal cancer } \\
\text { biomarkers }\end{array}$ & Rafter et al. (2007) \\
\hline $\begin{array}{l}\text { Return to pre-antibiotic baseline } \\
\text { flora }\end{array}$ & Engelbrektson et al. (2009) \\
\hline Epithelial barrier function & $\begin{array}{l}\text { Mennigen and Bruewer } \\
\text { (2009) }\end{array}$ \\
\hline $\begin{array}{l}\text { Increased natural killer cell } \\
\text { activity }\end{array}$ & $\begin{array}{l}\text { Takeda and Okumura } \\
\text { (2007) }\end{array}$ \\
\hline $\begin{array}{l}\text { Increased humoral immunity via } \\
\text { secretion of } \operatorname{IgA}\end{array}$ & Viljanen et al. (2005) \\
\hline Lowered blood cholesterol levels & Ataie-Jafari et al. (2009) \\
\hline $\begin{array}{l}\text { Reduction in irritable bowel } \\
\text { disease symptoms }\end{array}$ & MacFarlane et al. (2009) \\
\hline Delivery of therapeutics & $\begin{array}{l}\text { Wells and Mercenier } \\
\text { (2008) }\end{array}$ \\
\hline
\end{tabular}

Modified from O'Flaherty and Klaenhammer (2010a)

their ability to survive in the less-diverse small intestine. Members of the genus Bifidobacterium, of the phylum Actinobacteria, are Gram-positive, nonmotile, anaerobic bacteria, with low levels of genomic and phylogenetic diversity (Ventura et al. 2006). They
Table 2 Common probiotic Lactobacillus sp. and Bifidobacterium $\mathrm{sp}$.

\begin{tabular}{|c|c|}
\hline $\begin{array}{l}\text { Probiotic (strain } \\
\text { designation) }\end{array}$ & $\begin{array}{l}\text { Genome sequence reference } \\
\text { (accession number) }\end{array}$ \\
\hline \multicolumn{2}{|l|}{ Lactobacillus } \\
\hline $\begin{array}{l}\text { L. acidophilus } \\
\text { (NCFM, La-1) }\end{array}$ & $\begin{array}{l}\text { Altermann et al. (2005) } \\
\quad(\text { NC_006814.3) }\end{array}$ \\
\hline L. casei (BL23) & Maze et al. (2010) (NC_010999.1) \\
\hline $\begin{array}{l}\text { L. johnsonii (NCC } \\
\text { 533) }\end{array}$ & Pridmore et al. (2004) (NC_ 005632.1) \\
\hline $\begin{array}{l}\text { L. plantarum } \\
\text { (JDM1) }\end{array}$ & Zhang et al. (2009) (NC_012984.1) \\
\hline L. reuteri $(\mathrm{SD} 2112)$ & (NC_015697.1) \\
\hline L. rhamnosus $(\mathrm{GG})$ & $\begin{array}{l}\text { Kankainen et al. (2009) } \\
\text { (NC_013198.1) }\end{array}$ \\
\hline $\begin{array}{l}\text { L. salivarius } \\
\text { (UCC118) }\end{array}$ & Claesson et al. (2006) (NC_007929.1) \\
\hline $\begin{array}{l}\text { L. bulgaricus } \\
\text { (ATCC } \\
\text { 11842) }\end{array}$ & $\begin{array}{l}\text { van de Guchte et al. (2006) } \\
\text { (NC_008054.1) }\end{array}$ \\
\hline \multicolumn{2}{|l|}{ Bifidobacterium } \\
\hline $\begin{array}{l}\text { B. animalis subsp. } \\
\text { lactis (B1-04) }\end{array}$ & $\begin{array}{l}\text { Barrangou et al. (2009) } \\
\text { (NC_012814.1) }\end{array}$ \\
\hline $\begin{array}{l}\text { B. breve } \\
\text { (UCC2003) }\end{array}$ & $\begin{array}{l}\text { O'Connell Motherway et al. (2011) } \\
\text { (NC_020517.1) }\end{array}$ \\
\hline $\begin{array}{l}\text { B. longum (NCC } \\
\text { 2705) }\end{array}$ & Schell et al. (2002) (NC_004307.2) \\
\hline
\end{tabular}

were originally isolated from the faeces of breast-fed infants (Tissier 1900) and nearly 50 species isolated from the GIT of humans animals and insects have since been classified (Velez et al. 2007). In fact, bifidobacteria are among the most prominent commensal bacteria found in the human colon and dominate the developing microbiome in breast-fed infants (Turroni et al. 2008; Favier et al. 2002).

Since the resolution of the first bacterial genome sequence (Haemophilus influenzae), an exponential advancement in sequencing processing, genome assembly and annotation technologies, at increasingly economical pricing, has yielded well over a thousand publicly available genomes (Fleischmann et al. 1995; Lagesen et al. 2010). Notably, many of these genomes are derived from lactic acid bacteria used as probiotics or starter cultures for food fermentations (Klaenhammer et al. 2002; Lukjancenko et al. 2012). Access to these data has revolutionized the molecular view of probiotic bacteria, as well as the way research questions related to probiotic mechanisms are formulated. Specifically, advancements in genomic tools 


\section{Proteomics}

Analysis of proteins expressed, secreted, or attached to the cell wall
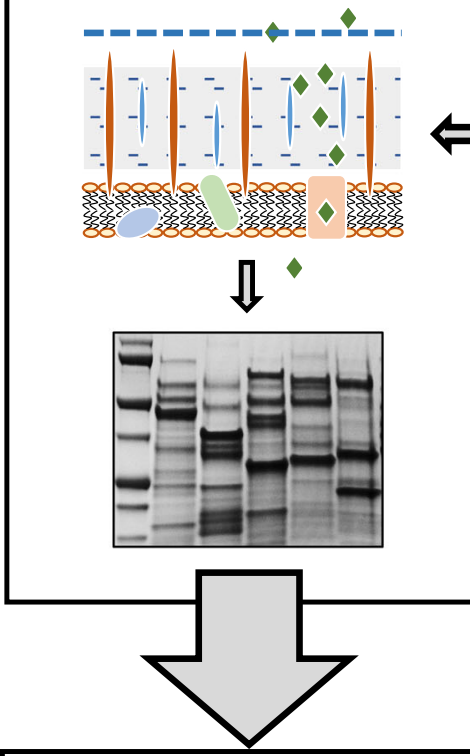

\section{Functional characterization of probiotic-host interactions}

Fig. 2 With the advent of genome sequencing, integrated genomic techniques including proteomics, transcriptomics and functional genomics have collectively characterized the mechanism of probiotic host-interactions. These analyses rely on access to annotated sequence data from whole genome sequencing. Genetic systems for deletions and mutational knockouts allow for phenotyping specific genetic loci. Proteomic approaches involve the characterization of proteins

including functional genomics, transcriptomics, proteomics and secretomics, have hastened research deciphering the interactions between probiotics and the GIT (Fig. 2). These techniques are being used to bridge the mechanistic gap between what has been seen clinically and anecdotally for hundreds of years.

Characterizing probiotic mechanisms using genomic tools

Referencing the genome sequences of probiotic bacteria, the mechanism and interaction of probiotics with the host GIT are being discovered through the integration of functional genomic techniques. Within this context, there are three points of focus relating to probiotic action: (i) survival through gastrointestinal transit and adhesion to intestinal epithelia; (ii) expressed, secreted, and/or attached to the cell wall. In this way, proteins are isolated, characterized by mass spectrometry, and mapped back to the proteome and corresponding genome for functional analysis. Finally, transcriptomic profiling using DNA microarrays, RNA sequencing, and RT-qPCR can measure the transcriptional responses of both bacteria and host cells in response to one another, via measurement of mRNA

competitive exclusion and antimicrobial activity; and (iii) modulation of the host GIT immune system (Fig. 3).

Survival in and adhesion to the GIT

One of the most essential qualities of a probiotic microorganism is the ability to survive the varied environments of the GIT (Fig. 3a). The probiotic must be able to adapt to acidic gastric juices and bile in the small intestine. Like many aciduric bacteria, the lipid membranes of lactobacilli exposed to acid and bile are altered in order to increase survival. The lipid membrane of Lactobacillus casei demonstrated a marked increase of mono-unsaturated fatty acids in response to acidification (Fozo et al. 2004). Similarly, the lipid membrane of Lactobacillus reuteri exposed 


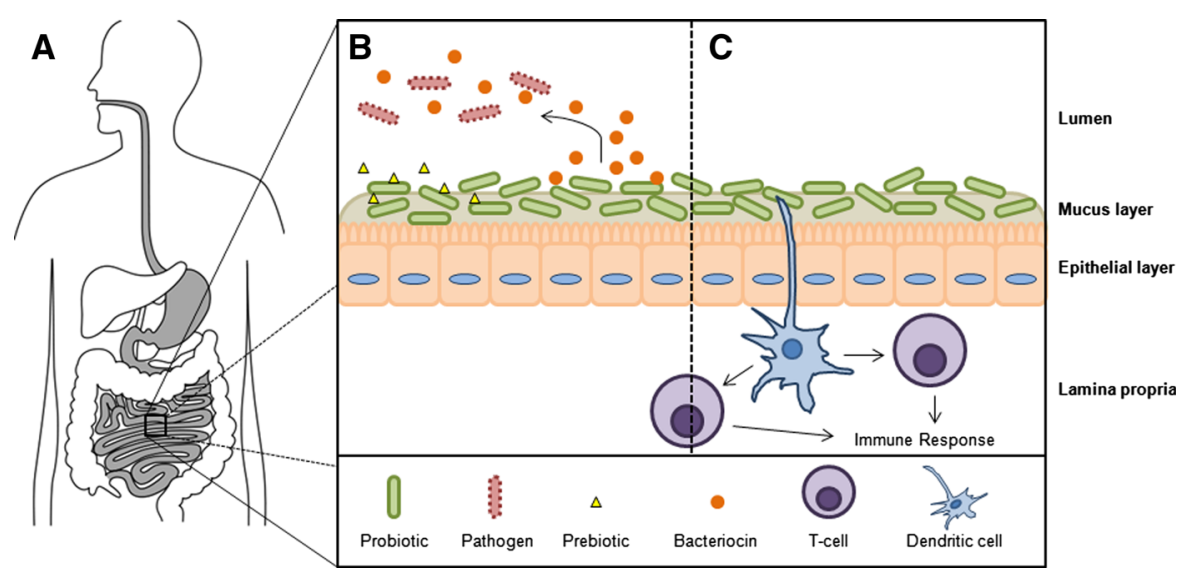

Fig. 3 a Probiotic microbes delivered orally must survive varying environments encountered through gastrointestinal transit, including acidic gastric juices $(\mathrm{pH} \sim 2)$ in the stomach, and bile in the small intestines. b At the intestinal epithelia, probiotics have been reported to adhere in high numbers, leading to competitive exclusion of pathogens. The growth of

to bile salts and cholesterol increased the number of mono-unsaturated fatty acids compared to saturated fatty acids (Taranto et al. 2003). Considering these observations, a recent study using the probiotic Lactobacillus rhamnosus GG found that an exogenous oleic acid [C18:1 (cis-9)] source significantly increased acid survival by incorporating the oleic acid into the membrane, which is reduced to stearic acid (C18:0) in the acidified environment (Corcoran et al. 2007). Aside from the biochemical changes to the lipid membranes, the Lactobacillus species have global transcriptional responses to these stressors, usually through two-component regulatory systems (2CRS; Lebeer et al. 2008b). Numerous transcriptomic analyses have been used in lactobacilli to identify differentially expressed genes, such as those corresponding to 2CRS, surface proteins and proton efflux systems, in response to gastric acid stress (Azcarate-Peril et al. 2005; Pieterse et al. 2005) and bile stress (Bron et al. 2006; Pfeiler et al. 2007). Bacteria quickly sense and respond to changing environmental conditions via 2CRS through the sensing domains of a transmembrane histidine protein kinase (HPK). Upon receiving the environmental signal, the HPK is activated to autophosphorylate a specific histidine residue which is transferred to the regulatory domain of the response regulator (RR), a DNA-binding transcriptional regulator. Therefore, $2 \mathrm{CRS}$ can be predicted from bacterial genome sequence annotations based on the presence certain probiotics can be stimulated by the presence of complex prebiotic oligosaccharides. Additionally, some probiotics produce bacteriocins and other antimicrobial agents which may antagonize pathogens in the lumen. c Probiotics bound in the mucus and epithelial layers are proximal to dendritic cells of the mucosal immune system, leading to immunomodulation

of putative HPK and RR in close proximity to one another (Altermann et al. 2005; Morita et al. 2009). In L. acidophilus NCFM, a gene (lba1524) encoding a functional HPK was knocked out, resulting in a mutant with increased sensitivity to acid stress compared to the parent strain. Furthermore, transcriptomic analysis via DNA microarray comparing the lba1524 mutant to wild-type demonstrated an impact on 80 genes (Azcarate-Peril et al. 2005). Notably, one upregulated gene in the HPK mutant was the LuxS homolog of the autoinducer-2 quorum sensing compound, important for survival in gastric juices and adhesion to intestinal epithelial cell lines (Lebeer et al. 2008a; Buck et al. 2009).

The response of lactobacilli to bile salts has also been measured through microarray analysis. In Lactobacillus plantarum a DNA-microarray was performed after exposure to porcine bile, resulting in the identification of bile response genes encoding stress response proteins, cell envelope proteins and an $\mathrm{F}_{0} \mathrm{~F}_{1}$ ATPase (Bron et al. 2006). A similar transcriptomic profiling of L. acidophilus revealed multiple genes involved in bile tolerance, including a $2 \mathrm{CRS}$ and multi-drug resistance (MDR) transporter efflux pumps (Pfeiler et al. 2007). Mutants with insertionally inactivated genes for the bile inducible 2CRS HPK and RR were more sensitive to bile compared to parent strains, confirming their role in bile tolerance (Pfeiler et al. 2007). A recent comparative proteomic analysis on bile sensitive and 
bile tolerant strains of $L$. plantarum corroborated these transcriptomic data and elucidated potential biomarkers for the selection of bile tolerant probiotic strains (Hao et al. 2011). Additionally, the role of efflux pumps and MDR transporters in probiotic bile tolerance are beginning to be recognized. Functional genomic analyses of MDR transporters in probiotic strains of $L$. reuterii and L. acidophilus demonstrated roles in bile tolerance (Whitehead et al. 2008; Pfeiler and Klaenhammer 2009). Furthermore, a MDR transporter gene in Bifidobacterium longum, betA (bile efflux transporter), was recently identified through in silico genome analysis and functionally characterized (Gueimonde et al. 2009). Heterologous expression of betA in Escherichia coli conferred bile tolerance through active efflux of bile salts.

Survivability and enhancement of beneficial microbes in the GIT can be accomplished by providing selectively utilizable carbohydrates, called prebiotics (Roberfroid 2007; Andersen et al. 2013). These carbohydrates, including $\beta$-galactooligosaccharide (GOS), lactulose, fructo-oligosaccharide and inulin, are resistant to gastric acidity, hydrolysis and gastrointestinal absorption (Roberfroid et al. 2010). As growth substrates, prebiotic carbohydrates are preferentially metabolized by species of health-promoting bacteria. Recently, differential transcriptomic and functional genomic analyses have demonstrated the capabilities of the probiotic bacteria $L$. acidophilus NCFM (Andersen et al. 2012) and Bifidobacterium lactis B1-04 (Andersen et al. 2013) to utilize prebiotic oligosaccharides. With these data, novel symbiotic formulations of corresponding prebiotics for $L$. acidophilus and B. lactis can be created to aid in the survival and probiotic effectiveness in the host small intestines and colon, respectively. In a similar vein, there is compelling evidence to suggest glycogen metabolism is a colonization factor for probiotic LAB. Glycogen is a large molecular mass, soluble $\alpha-1,4-$ linked glucose polymer with numerous $\alpha$-1,6-linked branches. It has multiple physiological functions in various bacteria and has been theorized to function as a carbon capacitor for the regulation of energy flux (Belanger and Hatfull 1999). Recent work by Goh and Klaenhammer (2013) demonstrated the functionality of a putative glycogen metabolism operon found in the genome sequence. Remarkably, through a series of chromosomal deletions and phenotypic assays, glycogen metabolism was found to regulate growth maintenance, bile tolerance and complex carbohydrate utilization in L. acidophilus (Goh and Klaenhammer 2013).

Beyond surviving gastrointestinal transit, a second key factor for probiotic activity is through adhesion to intestinal epithelia of the GIT. Preliminary in vitro studies using Caco-2 human intestinal epithelial cell lines revealed multiple probiotic lactobacilli with adhesive capabilities (Chauviere et al. 1992; Tuomola and Salminen 1998). Notably, there has also been work demonstrating the adhesiveness of Bifidobacterium spp. to human intestinal mucus (He et al. 2001). However, access to genome sequence data, paired with integrated genomic techniques, elucidated mediators of probiotic adhesion. The majority of these factors are secreted or attached to the cell wall in a sortase-dependent manner, in order to interface with the intestinal epithelia (reviewed by Velez et al. 2007 Lebeer et al. 2008b). In a study using L. plantarum WCFS1, two of these sortasedependent proteins (SDP) were found to be induced in the murine GIT (Bron et al. 2004a, b). Mutational analysis of one of these genes ( $\left.l p \_2940\right)$ resulted in a 100- to 1,000-fold decrease in persistence capacity of the L. plantarum lp_2940 knockout mutant in a mouse model. In L. acidophilus NCFM, in silico genome screening lead to the selection of five putative adhesion cell surface proteins, including a fibronectin binding protein (FbpA), S-layer protein (SlpA), mucin-binding protein (Mub) and two R28 homologues involved in streptococcal adhesion (Buck et al. 2005). Through mutational analysis, FbpA, Mub, and SlpA were all found to contribute to adhesion to Caco-2 epithelial cell lines. Similarly, a stress response protein and an aggregation-promoting factor (both cell surface proteins) were found in later studies to contribute to adherence to Caco-2 cells (O'Flaherty and Klaenhammer 2010b; Goh and Klaenhammer 2010). In Lactobacillus crispatus JCM5810, the S-layer protein (CbsA) contains domains that bind to laminin and collagens (Antikainen et al. 2002). Genome screening and secretome analysis of Lactobacillus salivarius UCC118 led to the identification of three SDPs with mucus-binding domains. A sortase-deficient strain was created, resulting in significantly reduced adherence to Caco-2 and HT-29 cell lines in vitro (van Pijkeren et al. 2006). Notably, genomic analysis between two strains of L. rhamnosus revealed the presence of a 


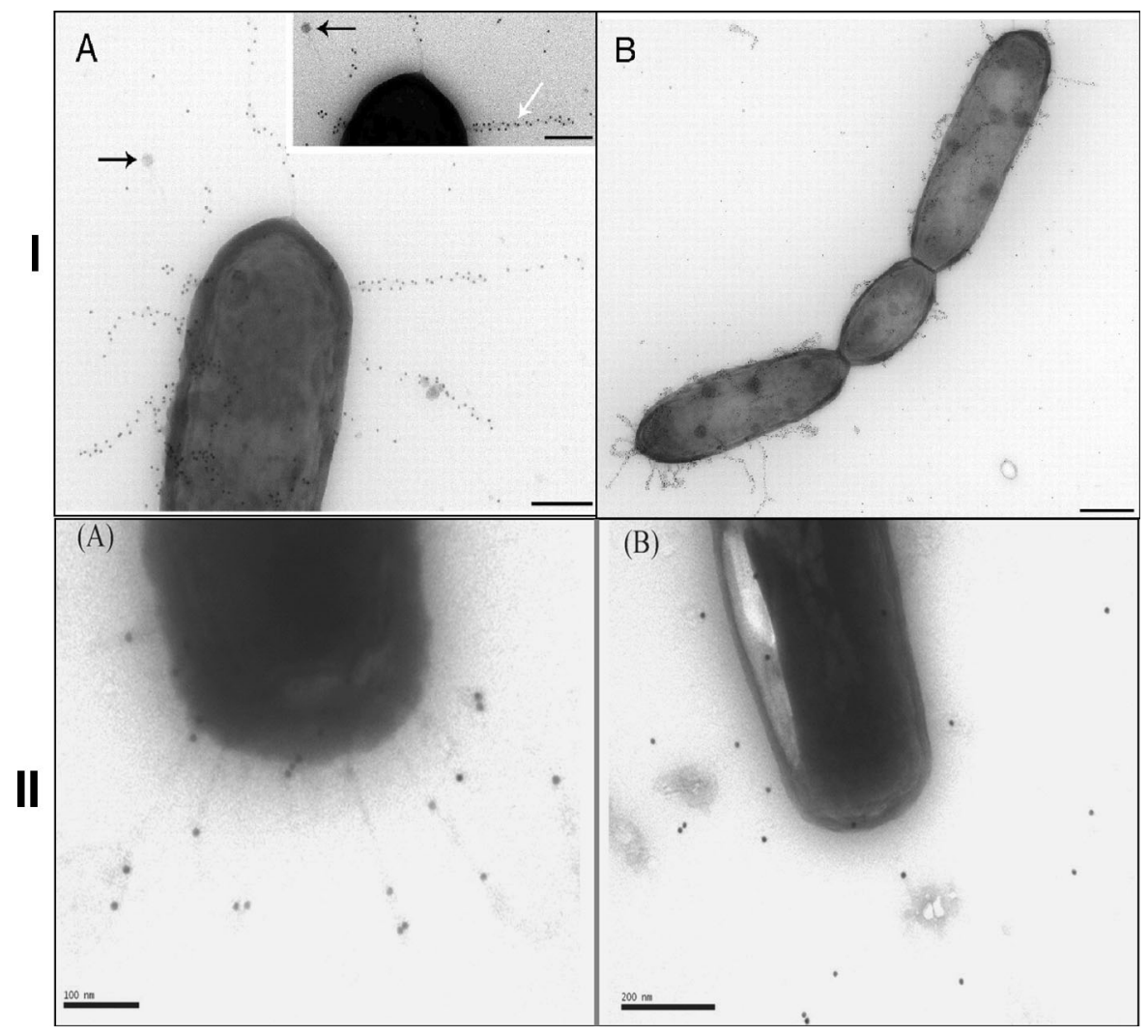

Fig. 4 Identification of pili structures in Lactobacillus rhamnosus GG (I) and Bifidobacterium breve UCC2003 (II). Images were obtained using transmission electron microscopy on negatively stained, immunogold-labeled anti-SpaC pili in $L$. rhamnosus (I) and anti-Flp $p_{2003}$ pili in $B$. breve (II). Reprinted

genomic island in L. rhamnosus GG that contained three secreted, sortase-dependent pilins encoded by spaCBA (Kankainen et al. 2009). Immunoblotting and immunogold electron microscopy confirmed the formation of cell wall-bound pili (Fig. 4). Furthermore, mutational analysis of the spaC gene abolished the adherence capability of L. rhamnosus GG to human intestinal mucus, implicating the role of these unique pili structures in adherence and retention in the GIT. Since this initial report, a type IVb tight adherence (Tad) pilus-encoding gene cluster has been identified in Bifidobacterium breve UCC2003 (O'Connell Motherway et al. 2011; Fig. 4). Mutational analysis demonstrated that the Tad gene cluster was essential for colonization in a murine model. Collectively, these data suggest that there are multiple cell surface factors which contribute to probiotic adherence to human intestinal epithelia. with permission from Kankainen et al. (2009), copyright (C) 2009 National Academy of Sciences, USA; and O'Connell Motherway et al. (2011), copyright (C) 2011 National Academy of Sciences USA

\section{Competitive exclusion and antimicrobial activity}

Another health-promoting aspect of probiotic bacteria is the prevention of pathogenic infection (Fig. 3b). When probiotic lactobacilli are ingested, they temporarily coat the mucosal layer and epithelia of the small intestine (see above) leading to both physical and chemical barriers against harmful bacteria (Servin 2004). Initial studies demonstrated that lactobacilli inhibited adherence of Gram-negative uropathogens when uroepithelial cells were pre-incubated with whole, viable Lactobacillus (Chan et al. 1985). Furthermore, in vivo mice models demonstrated that L. casei GR1 was capable of preventing urinary tract infections from E. coli, Klebsiella pneumoniae, and Pseudomonus aeruginosa (Reid et al. 1985). In both cases, the mechanism of pathogenic antagonism was due to the ability of lactobacilli to adhere to the 
urogenital epithelia, thus preventing infection through competitive exclusion of the pathogen. These studies and others suggested that similar competitive exclusion could be possible in the human GIT using probiotic lactobacilli and bifidobacteria. In fact, numerous studies have demonstrated the in vitro inhibition of numerous gastrointestinal pathogens through competitive exclusion of probiotic lactobacilli and bifidobacteria using intestinal cell lines (reviewed by: Servin 2004).

In addition to competitive exclusion of pathogens, probiotic bacteria produce numerous chemical antimicrobials which may prevent pathogenic infection. These include: hydrogen peroxide (St Amant et al. 2002; Pridmore et al. 2008), lactic acid (FayolMessaoudi et al. 2005), biosurfactants (Velraeds et al. 1996), immunomodulatory products (Ryan et al. 2009) and bacteriocins (Dobson et al. 2012). Bacteriocins are bacterially derived antimicrobial peptides that are active against other bacteria, but to which the producing bacterium is immune (Cotter et al. 2005). Lactic acid bacteria produce numerous broadspectrum bacteriocins which are divided into three main classes: class I bacteriocins (lantibiotics; Schnell et al. 1988), small peptides possessing lanthionine residues; class II bacteriocins, which are heat-stable and do not contain lanthionine residues; and bacteriolysins, which are large, heat-labile murein hydrolases (Cotter et al. 2005; Fig. 5). Historically, scientists have sought to characterize the genetics and biochemistry of bacteriocins produced by $\mathrm{LAB}$, in part due to their safety implications in the dairy fermentation industries (Klaenhammer 1993; Nes et al. 1996). In fact, one of the most industrially relevant bacteriocins is nisin, a lantibiotic produced by Lactococcus lactis (DelvesBroughton et al. 1996). Nisin has two modes of bacteriocidal activity (Fig. 5). First, it can bind lipid II, the main transporter of peptidoglycan subunits, disrupting cell wall synthesis (Breukink et al. 1999). Nisin also targets lipid II as a docking mechanism for pore formation, leading to rapid cell death due to disruption of the proton motive force (Wiedemann et al. 2001). Notably, Gram-positive bacteriocins generally have a narrow range of toxicity, as they are primarily lethal to closely related bacterial species such as Staphylococcus, Listeria and other LAB (Servin 2004). Most research involving $\mathrm{LAB}$-associated bacteriocins has been in vitro. However, a landmark study by Corr et al. (2007) demonstrated that a bacteriocin produced by $L$. salivarius UCC118 caused in vivo protection in mice challenged with the food-borne pathogen Listeria monocytogenes. Using a functional genomics-based mutational analysis, generating a stable $L$. salivarius UCC118 strain deficient in bacteriocin production, undoubtedly established the role of this bacteriocin in protection against $L$. monocytogenes infection.

Probiotic modulation of the gastrointestinal mucosal immune system

Perhaps one of the most important aspects of probiotic bacteria is the ability to modulate the host GIT mucosal immune system locally and systemically (Fig. 3c). The interaction between the probiotic microbe with the resident microbiota, gastrointestinal epithelia and gut immune cells to produce an immunomodulatory response is quite complex, and has been reviewed exhaustively (Lebeer et al. 2010; O'Flaherty and Klaenhammer 2010a; Reid et al. 2011; Bron et al. 2012; Klaenhammer et al. 2012; Selle and Klaenhammer 2013). Probiotic microbes modulate mucosal immunity through the interaction of proteinacious microorganism-associated molecular patterns (MAMPs) with pattern recognition receptors (PRRs) on antigen-presenting cells (APCs), such as dendritic cells and macrophages. Upon exposure to MAMPs, the PRRs (including NOD-like receptors, Toll-like receptors, and C-type lectin receptors) activate nuclear factor (NF) $-\kappa B$ and mitogen-activated protein kinase signaling cascades, which modulate the expression of cytokine and chemokine genes. The most common MAMPs from probiotic microorganisms are lipoteichoic acids (LTA), peptidoglycan and S-layer proteins (Bron et al. 2012). Multiple studies have explored the immunomodulatory effect of these MAMPs using functional genomic techniques. In a seminal study, the probiotics L. casei and L. reuteri were found to induce IL-10 producing regulatory T-cells through the modulation of the DC-specific ICAM-3-grabbing nonintegrin (DC-SIGN; Smits et al. 2005). Targeting of DCSIGN by probiotic bacteria is potentially an important factor for treatment of inflammatory conditions via the production of anti-inflammatory IL-10. The S-layer protein (SIpA) of L. acidophilus NCFM was found to bind DC-SIGN, which regulate immature DC and T cell functionality (Konstantinov et al. 2008). Using $L$. plantarum NCIMB8826, cell wall composition was examined for immunomodulatory effects by creating a 
Fig. 5 Bacteriocins produced by LAB are grouped into three classes based on structure and function: class I (lantibiotics), class II, and bacteriolysins. Class I lantibiotics, such as nisin, can have two modes of action. First, they bind lipid II to prevent peptidoglycan subunit transport, disrupting peptidoglycan synthesis and cell division. Second, they dock at lipid II to create pores in the cytoplasmic membrane of the bacteria. Class II bacteriocins, such as sakacin, often contain amphiphilic helical structures which can insert into the cell membrane, leading to cell lysis. Bacteriolysins, such as lyostaphin, are large hydrolases which directly degrade the peptidoglycan cell wall. Reprinted with permission of Macmillan Publishers, Ltd, from Cotter et al. (2005), copyright (C) 2005 Nature Publishing Group

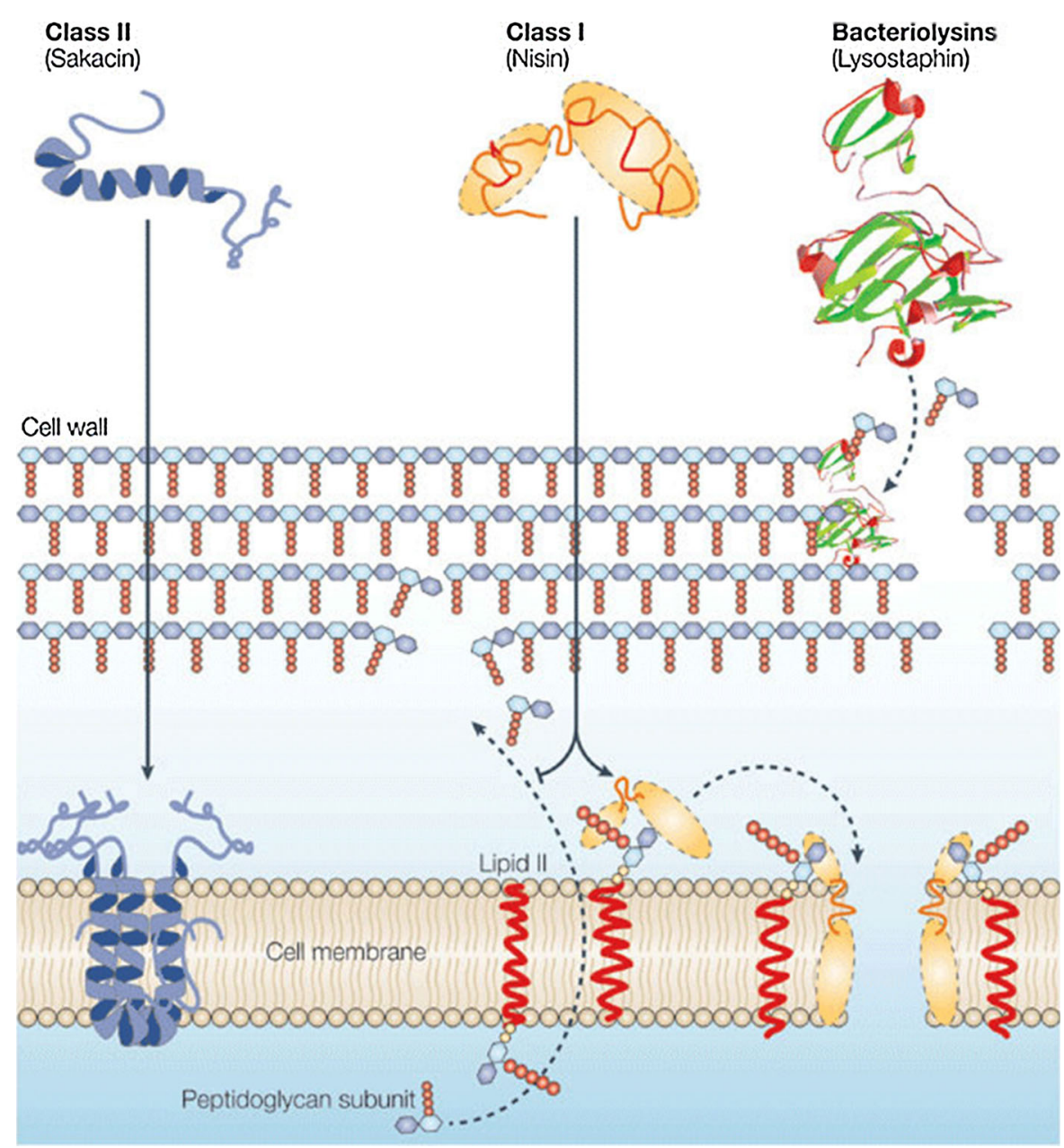

mutant $\left(d l t^{-}\right)$which produced modified teichoic acids with less D-alanine than the parent strain (Grangette et al. 2005). The mutant demonstrated a significant reduction in production of proinflammatory cytokines compared to wild type, along with a simultaneous increase in anti-inflammatory IL-10. Furthermore, the $d l t^{-}$mutant was more protective in an in vivo murine colitis model than the parent strain (Grangette et al. 2005). An LTA-deficient strain of L. acidophilus NCFM, created by a clean deletion of the $1 b a 0447$ phosphoglycerol transferase, was able to abate induced colonic-inflammation in a colitis mouse model through the down regulation of pro-inflammatory IL-12 and TNF- $\alpha$ and the up regulation of anti-inflammatory IL10 (Mohamadzadeh et al. 2011). Additionally, this same mutant reduced colonic polyposis in a colon cancer mouse model, through the normalization of pathogenic immune responses (Khazaie et al. 2012).
Like many probiotic effectors, most MAMPs are found on the cell surface of Gram-positive microbes. Recently, the genomes and proteomes of several lactobacilli were bioinformatically screened to create a secretome database cataloging the various extracellular proteins in LAB (Kleerebezem et al. 2010; Zhou et al. 2010). Consequently, using in silico genome analysis and by reference to the LAB secretome, a putative MAMP can be selected and validated through mutagenesis (Bron et al. 2012). Indeed, a recent study of $L$. acidophilus used a proteomic-based method to identify S-layer associated proteins (SLAPs) in situ (Johnson et al. 2013). After extraction, the SLAPs were identified through mass spectrometry and referenced to the LAB secretome. Mutational analysis of one SLAP (lba1029), revealed an immunomodulatory phenotype using in vitro bacterial-DC co-incubation assays, suggesting the potential of multiple unknown 
MAMPs associated with the S-layer of L. acidophilus NCFM. Researchers are also trying to understand the complex dynamic of host-microbe crosstalk by using whole transcriptome profiling of human intestinal epithelia upon exposure to probiotics. In one study, transcriptomes were obtained from the mucosa of the proximal small intestines of healthy volunteers exposed to probiotic $L$. acidophilus, $L$. casei, and $L$. rhamnosus (van Baarlen et al. 2011). The transcriptional networks induced by each probiotic were unique to each strain and remarkably similar to response profiles obtained from bioactive components and drug treatments. In vitro transcriptome profiling of Caco-2 intestinal epithelial cell lines exposed to L. acidophilus NCFM corroborated these data (O'Flaherty and Klaenhammer 2012). Similarly, Bifidobacterium bifidum PRL2010 transcriptome analyses with both in vitro human cell lines and in vivo murine models demonstrated the capacity for strain PRL2010 to modulate host innate immunity (Turroni et al. 2014).

\section{Conclusions and future directions}

While the paradigm of discovery based genomics in probiotic LAB has uncovered vital aspects of probiotic mechanisms, it has also revealed the complexity of these interactions with the resident microbiota and the mucosal immune system. But with this challenge has come great opportunity. For example, probiotic bacteria are now being explored as suitable models for vaccine/drug delivery, due to their close association with host immunity and immunomodulatory action (Kajikawa et al. 2011; Stoeker et al. 2011; Kajikawa et al. 2012). Furthermore, recent discoveries are also demonstrating that the roles of probiotic bacteria and the resident microbiota extend far beyond gastrointestinal health. Specifically, studies on the bi-directional crosstalk between the GIT and the brain (the gut-brain axis) are revealing the neurochemical importance of gut homeostasis (Cryan and Mahony 2011; Bercik et al. 2012). Along with these advancements, it is important that human clinical trials continue with experimental designs that are well-controlled and welldefined, reflecting the great progress that has been made in the field of probiotic and GIT microbiome research (reviewed by Sanders et al. 2013). With more than a century passing since Metchnikoff's observations, keen experimental design using integrated genomics has led to a clearer definition of probiotic bacteria, as well as a model for continued discovery.

Acknowledgments Research on the functional genomics of probiotic microbes in the Klaenhammer group is partially supported by the North Carolina Agricultural Foundation and Danisco/Dupont Nutrition and Health. The authors wish to thank Dr. Sarah O'Flaherty for helpful discussion on figure design.

Open Access This article is distributed under the terms of the Creative Commons Attribution License which permits any use, distribution, and reproduction in any medium, provided the original author(s) and the source are credited.

\section{References}

Altermann E, Russell WM, Azcarate-Peril MA, Barrangou R, Buck BL, McAuliffe O, Souther N, Dobson A, Duong T, Callanan M, Lick S, Hamrick A, Cano R, Klaenhammer TR (2005) Complete genome sequence of the probiotic lactic acid bacterium Lactobacillus acidophilus NCFM. Proc Natl Acad Sci USA 102(11):3906-3912. doi:10.1073/ 0409188102

Andersen JM, Barrangou R, Hachem MA, Lahtinen SJ, Goh YJ, Svensson B, Klaenhammer TR (2012) Transcriptional analysis of prebiotic uptake and catabolism by Lactobacillus acidophilus NCFM. PLoS ONE 7(9):e44409. doi:10. 1371/0044409

Andersen JM, Barrangou R, Abou-Hachem M, Lahtinen SJ, Goh YJ, Svensson B, Klaenhammer TR (2013) Transcriptional analysis of oligosaccharide utilization by Bifidobacterium lactis B1-04. BMC Genom 14:312. doi:10. 1186/1471-2164-14-312

Antikainen J, Anton L, Sillanpaa J, Korhonen TK (2002) Domains in the S-layer protein CbsA of Lactobacillus crispatus involved in adherence to collagens, laminin and lipoteichoic acids and in self-assembly. Mol Microbiol 46(2):381-394. doi:10.1046/1365-2958.2002.03180

Ataie-Jafari A, Larijani B, Alavi-Majd H, Tahbaz F (2009) Cholesterol-lowering effect of probiotic yogurt in comparison with ordinary yogurt in mildly to moderately hypercholesterolemic subjects. Ann Nutr Metab 54(1): 22-27. doi:10.1159/000203284

Azcarate-Peril MA, McAuliffe O, Altermann E, Lick S, Russell WM, Klaenhammer TR (2005) Microarray analysis of a two-component regulatory system involved in acid resistance and proteolytic activity in Lactobacillus acidophilus. Appl Environ Microbiol 71(10):5794-5804. doi:10.1128/ 71.10.5794-5804.2005

Barrangou R, Briczinski EP, Traeger LL, Loquasto JR, Richards M, Horvath P, Coute-Monvoisin AC, Leyer G, Rendulic S, Steele JL, Broadbent JR, Oberg T, Dudley EG, Schuster S, Romero DA, Roberts RF (2009) Comparison of the complete genome sequences of Bifidobacterium animalis subsp. lactis DSM 10140 and B1-04. J Bacteriol 191(13):4144-4151. doi:10.1128/00155-09 
Belanger AE, Hatfull GF (1999) Exponential-phase glycogen recycling is essential for growth of Mycobacterium smegmatis. J Bacteriol 181(21):6670-6678

Bercik P, Collins SM, Verdu EF (2012) Microbes and the gutbrain axis. Neurogastroenterol Motil 24(5):405-413. doi:10.1111/1365-2982.2012.01906

Bibel DJ (1988) Elie Metchnikoff's Bacillus of long life. ASM News 54:661-665

Breukink E, Wiedemann I, van Kraaij C, Kuipers OP, Sahl HG, de Kruijff B (1999) Use of the cell wall precursor lipid II by a pore-forming peptide antibiotic. Science 286(5448): 2361-2364. doi:10.1126/286.5448.2361

Bron PA, Marco M, Hoffer SM, Van Mullekom E, de Vos WM, Kleerebezem M (2004a) Genetic characterization of the bile salt response in Lactobacillus plantarum and analysis of responsive promoters in vitro and in situ in the gastrointestinal tract. J Bacteriol 186(23):7829-7835. doi:10. 1128/186.23.7829-7835.2004

Bron PA, Grangette C, Mercenier A, de Vos WM, Kleerebezem M (2004b) Identification of Lactobacillus plantarum genes that are induced in the gastrointestinal tract of mice. J Bacteriol 186(17):5721-5729. doi:10.1128/186.17.57215729.2004

Bron PA, Molenaar D, de Vos WM, Kleerezebem M (2006) DNA micro-array-based identification of bile-responsive genes in Lactobacillus plantarum. J Appl Microbiol 100(4):728-738. doi:10.1111/1365-2672.2006.02891

Bron PA, van Baarlen P, Kleerebezem M (2012) Emerging molecular insights into the interaction between probiotics and the host intestinal mucosa. Nat Rev Microbiol 10(1):66-78. doi:10.1038/2690

Buck BL, Altermann E, Svingerud T, Klaenhammer TR (2005) Functional analysis of putative adhesion factors in Lactobacillus acidophilus NCFM. Appl Environ Microbiol 71(12):8344-8351. doi:10.1128/71.12.8344-8351.2005

Buck BL, Azcarate-Peril MA, Klaenhammer TR (2009) Role of autoinducer-2 on the adhesion ability of Lactobacillus acidophilus. J Appl Microbiol 107(1):269-279. doi:10. 1111/1365-2672.2009.04204

Chan RC, Reid G, Irvin RT, Bruce AW, Costerton JW (1985) Competitive exclusion of uropathogens from human uroepithelial cells by Lactobacillus whole cells and cell wall fragments. Infect Immun 47(1):84-89

Chauviere G, Coconnier MH, Kerneis S, Fourniat J, Servin AL (1992) Adhesion of human Lactobacillus acidophilus strain LB to human enterocyte-like Caco-2 cells. Microbiology 138(Pt 8):1689-1696

Claesson MJ, Li Y, Leahy S, Canchaya C, van Pijkeren JP, Cerdeno-Tarraga AM, Parkhill J, Flynn S, O'Sullivan GC, Collins JK, Higgins D, Shanahan F, Fitzgerald GF, van Sinderen D, O'Toole PW (2006) Multireplicon genome architecture of Lactobacillus salivarius. Proc Natl Acad Sci USA 103(17):6718-6723. doi:10.1073/0511060103

Cohendy M (1906a) Déscription d'un ferment lactique puissant capable de s'acclimater dans l'intestin d'homme. Comptes redus des séances et mémoirs de la société de biologie 60:558-560

Cohendy M (1906b) Essai de traitement de l'enterite mucomembraneuse aigue par l'acclimation d'un ferment lactique dans le gros intestine. Comptes redus des séances et mémoirs de la société de biologie 60:363
Corcoran BM, Stanton C, Fitzgerald GF, Ross RP (2007) Growth of probiotic lactobacilli in the presence of oleic acid enhances subsequent survival in gastric juice. Microbiology 153(1):291-299

Corr SC, O’Neill LA (2009) Listeria monocytogenes infection in the face of innate immunity. Cell Microbiol 11(5): 703-709. doi:10.1111/1462-5822.2009.01294.x

Corr SC, Li Y, Riedel CU, O'Toole PW, Hill C, Gahan CG (2007) Bacteriocin production as a mechanism for the antiinfective activity of Lactobacillus salivarius UCC118. Proc Natl Acad Sci USA 104(18):7617-7621. doi:10.1073/ 0700440104

Cotter PD, Hill C, Ross RP (2005) Bacteriocins: developing innate immunity for food. Nat Rev Microbiol 3(10): 777-788. doi: $10.1038 / 1273$

Cryan JF, Mahony SM (2011) The microbiome-gut-brain axis: from bowel to behavior. Neurogastroenterol Motil 23(3):187-192. doi:10.1111/j.1365-2982.2010.01664.x

Delves-Broughton J, Blackburn P, Evans RJ, Hugenholtz J (1996) Applications of the bacteriocin, nisin. Antonie Van Leeuwenhoek 69(2):193-202

Deshpande G, Rao S, Patole S, Bulsara M (2010) Updated metaanalysis of probiotics for preventing necrotizing enterocolitis in preterm neonates. Pediatrics 125(5):921-930. doi:10.1542/2009-1301

Dobson A, Cotter PD, Ross RP, Hill C (2012) Bacteriocin production: a probiotic trait? Appl Environ Microbiol 78(1):1-6. doi:10.1128/05576-11

Douglas GL, Klaenhammer TR (2010) Genomic evolution of domesticated microorganisms. Annu Rev Food Sci Technol 1:397-414. doi:10.1146/102308.124134

Engelbrektson A, Korzenik JR, Pittler A, Sanders ME, Klaenhammer TR, Leyer G, Kitts CL (2009) Probiotics to minimize the disruption of faecal microbiota in healthy subjects undergoing antibiotic therapy. J Med Microbiol 58(Pt 5):663-670. doi:10.1099/0.47615-0

FAO/WHO (2002) Guidelines for the Evaluation of Probiotics in Food. FAO/WHO, London, ON, Canada

Favier CF, Vaughan EE, De Vos WM, Akkermans AD (2002) Molecular monitoring of succession of bacterial communities in human neonates. Appl Environ Microbiol 68(1):219-226

Fayol-Messaoudi D, Berger CN, Coconnier-Polter MH, Le Lievin-Moal V, Servin AL (2005) pH-, Lactic acid-, and non-lactic acid-dependent activities of probiotic Lactobacilli against Salmonella enterica serovar Typhimurium. Appl Environ Microbiol 71(10):6008-6013. doi:10.1128/ 71.10.6008-6013.2005

Fleischmann RD, Adams MD, White O, Clayton RA, Kirkness EF, Kerlavage AR, Bult CJ, Tomb JF, Dougherty BA, Merrick JM et al (1995) Whole-genome random sequencing and assembly of Haemophilus influenzae Rd. Science 269(5223):496-512

Foligne B, Daniel C, Pot B (2013) Probiotics from research to market: the possibilities, risks and challenges. Curr Opin Microbiol 16(3):284-292. doi:10.1016/2013.06.008

Fozo EM, Kajfasz JK, Quivey RG (2004) Low pH-induced membrane fatty acid alterations in oral bacteria. FEMS Microbiol Lett 238:291-295. doi:10.1016/2004.07.047

Fujimura S, Watanabe A, Kimura K, Kaji M (2012) Probiotic mechanism of Lactobacillus gasseri OLL2716 strain 
against Helicobacter pylori. J Clin Microbiol 50(3):1134-1136. doi:10.1128/06262-11

Gao XW, Mubasher M, Fang CY, Reifer C, Miller LE (2010) Dose-response efficacy of a proprietary probiotic formula of Lactobacillus acidophilus CL1285 and Lactobacillus casei LBC80R for antibiotic-associated diarrhea and Clostridium difficile-associated diarrhea prophylaxis in adult patients. Am J Gastroenterol 105(7):1636-1641. doi: $10.1038 / 2010.11$

Gasser F (1970) Electrophoretic characterization of lactic dehydrogenases in the genus Lactobacillus. Microbiology 62(2):223-239

Gasser F, Doudoroff M, Contopoulos R (1970) Purification and properties of NAD-dependent lactic dehydrogenases of different species of lactobacillus. Microbiology 62(2):241-250

Goh YJ, Klaenhammer TR (2010) Functional roles of aggregation-promoting-like factor in stress tolerance and adherence of Lactobacillus acidophilus NCFM. Appl Environ Microbiol 76(15):5005-5012. doi:10.1128/00030-10

Goh YJ, Klaenhammer TR (2013) A functional glycogen biosynthesis pathway in Lactobacillus acidophilus: expression and analysis of the glg operon. Mol Microbiol 89(6):1187-1200. doi:10.1111/12338

Grangette C, Nutten S, Palumbo E, Morath S, Hermann C, Dewulf J, Pot B, Hartung T, Hols P, Mercenier A (2005) Enhanced antiinflammatory capacity of Lactobacillus plantarum mutant synthesizing modified teichoic acids. Proc Natl Acad Sci USA 102(29):10321-10326. doi:10. 1073/s.0504084102

Gueimonde M, Garrigues C, van Sinderen D, de los ReyesGavilan CG, Margolles A (2009) Bile-inducible efflux transporter from Bifidobacterium longum NCC2705, conferring bile resistance. J Bacteriol 75(10):3153-3160. doi:10.1128/00172-09

Hammes WP, Vogel RF (1995) The genus Lactobacillus. In: Ludwig S (ed) The genera of lactic acid bacteria. Blackie Academic and Professional, Glasgow, pp 19-54

Hao Q, Lu Z, Dong BR, Huang CQ, Wu T (2011) Probiotics for preventing acute upper respiratory tract infections. Cochrane Database Syst Rev. doi:10.1002/14651858

He F, Ouwehan AC, Hashimoto H, Isolauri E, Benno Y, Salminen S (2001) Adhesion of Bifidobacterium spp. to human intestinal mucus. Microbiol Immunol 45(3):259-262

Hosono A (1992) Fermented milk in the orient in Functions of Fermented Milk: Challenges for the Health Sciences. Elsevier, Barking, pp 61-78

Hungin AP, Mulligan C, Pot B, Whorwell P, Agreus L, Fracasso P, Lionis C, Mendive J, de Philippart Foy JM, Rubin G, Winchester C, Wit N, European Society for Primary Care G (2013) Systematic review: probiotics in the management of lower gastrointestinal symptoms in clinical practice-an evidence-based international guide. Aliment Pharmacol Ther 38(8):864-886. doi:10.1111/12460

Johnson B, Selle K, O'Flaherty S, Goh YJ, Klaenhammer T (2013) Identification of extracellular surface-layer associated proteins in Lactobacillus acidophilus NCFM. Microbiology 159(Pt 11):2269-2282. doi:10.1099/0.070755-0

Kajikawa A, Nordone SK, Zhang L, Stoeker LL, LaVoy AS, Klaenhammer TR, Dean GA (2011) Dissimilar properties of two recombinant Lactobacillus acidophilus strains displaying Salmonella FliC with different anchoring motifs.
Appl Environ Microbiol 77(18):6587-6596. doi:10.1128/ 05153-11

Kajikawa A, Zhang L, Long J, Nordone S, Stoeker L, LaVoy A, Bumgardner S, Klaenhammer T, Dean G (2012) Construction and immunological evaluation of dual cell surface display of HIV-1 gag and Salmonella enterica serovar Typhimurium FliC in Lactobacillus acidophilus for vaccine delivery. Clin Vaccine Immunol 19(9):1374-1381. doi:10. 1128/00049-12

Kankainen M, Paulin L, Tynkkynen S, von Ossowski I, Reunanen J, Partanen P, Satokari R, Vesterlund S, Hendrickx AP, Lebeer S, De Keersmaecker SC, Vanderleyden J, Hamalainen T, Laukkanen S, Salovuori N, Ritari J, Alatalo E, Korpela R, Mattila-Sandholm T, Lassig A, Hatakka K, Kinnunen KT, Karjalainen H, Saxelin M, Laakso K, Surakka A, Palva A, Salusjarvi T, Auvinen P, de Vos WM (2009) Comparative genomic analysis of Lactobacillus rhamnosus GG reveals pili containing a human- mucus binding protein. Proc Natl Acad Sci USA 106(40):1719317198. doi:10.1073/s.0908876106

Khazaie K, Zadeh M, Khan MW, Bere P, Gounari F, Dennis K, Blatner NR, Owen JL, Klaenhammer TR, Mohamadzadeh M (2012) Abating colon cancer polyposis by Lactobacillus acidophilus deficient in lipoteichoic acid. Proc Natl Acad Sci USA 109(26):10462-10467. doi:10.1073/s.1207230109

Klaenhammer TR (1993) Genetics of bacteriocins produced by lactic acid bacteria. FEMS Microbiol Rev 12(1-3):39-85

Klaenhammer T, Altermann E, Arigoni F, Bolotin A, Breidt F, Broadbent J, Cano R, Chaillou S, Deutscher J, Gasson M, van de Guchte M, Guzzo J, Hartke A, Hawkins T, Hols P, Hutkins R, Kleerebezem M, Kok J, Kuipers O, Lubbers M, Maguin E, McKay L, Mills D, Nauta A, Overbeek R, Pel H, Pridmore D, Saier M, van Sinderen D, Sorokin A, Steele J, O'Sullivan D, de Vos W, Weimer B, Zagorec M, Siezen R (2002) Discovering lactic acid bacteria by genomics. Antonie Van Leeuwenhoek 82(1-4):29-58

Klaenhammer TR, Kleerebezem M, Kopp MV, Rescigno M (2012) The impact of probiotics and prebiotics on the immune system. Nat Rev Immunol 12(10):728-734. doi: $10.1038 / 3312$

Kleerebezem M, Hols P, Bernard E, Rolain T, Zhou M, Siezen RJ, Bron PA (2010) The extracellular biology of the Lactobacilli. FEMS Microbiol Rev 34(2):199-230. doi:10. 1111/1574-6976.2010.00208

Konstantinov SR, Smidt H, de Vos WM, Bruijns SC, Singh SK, Valence F, Molle D, Lortal S, Altermann E, Klaenhammer TR, van Kooyk Y (2008) S layer protein A of Lactobacillus acidophilus NCFM regulates immature dendritic cell and T cell functions. Proc Natl Acad Sci USA 105(49):19474 19479. doi:10.1073/s.0810305105

Lagesen K, Ussery DW, Wassenaar TM (2010) Genome update: the 1,000th genome-a cautionary tale. Microbiology 156(Pt 3):603-608. doi:10.1099/0.038257-0

Lebeer S, Claes IJ, Verhoeven TL, Shen C, Lambrichts I, Ceuppens JL, Vanderleyden J, De Keersmaecker SC (2008a) Impact of luxS and suppressor mutations on the gastrointestinal transit of Lactobacillus rhamnosus GG. Appl Environ Microbiol 74(15):4711-4718. doi:10.1128/00133-08

Lebeer S, Vanderleyden J, De Keersmaecker SC (2008b) Genes and molecules of lactobacilli supporting probiotic action. Microbiol Mol Biol Rev 72(4):728-764. doi:10.1128/00017-08 
Lebeer S, Vanderleyden J, De Keersmaecker SC (2010) Host interactions of probiotic bacterial surface molecules: comparison with commensals and pathogens. Nat Rev Microbiol 8(3):171-184. doi:10.1038/2297

Lee YK, Puong KY, Ouwehand AC, Salminen S (2003) Displacement of bacterial pathogens from mucus and Caco-2 cell surface by lactobacilli. J Med Microbiol 52(10):925-930

Leyer GJ, Li S, Mubasher ME, Reifer C, Ouwehand AC (2009) Probiotic effects on cold and influenza-like symptom incidence and duration in children. Pediatrics 124(2): 172-179. doi:10.1542/2008-2666

Lukjancenko O, Ussery DW, Wassenaar TM (2012) Comparative genomics of Bifidobacterium, Lactobacillus and related probiotic genera. Microb Ecol 63(3):651-673. doi:10. 1007/s00248-011-9948

Macfarlane GT, Blackett KL, Nakayama T, Steed H, Macfarlane S (2009) The gut microbiota in inflammatory bowel disease. Curr Pharm Des 15(13):1528-1536

Mattila-Sandholm T, Blum S, Collins JK, Crittenden R, de Vos W, Dunne C, Fondén R, Grenov G, Isolauri E, Kiely B, Marteau P, Morelli L, Ouwehand A, Reniero R, Saarela M, Salminen S, Saxelin M, Schiffrin E, Shanahan F, Vaughan E, von Wright A (1999) Probiotics: towards demonstrating efficacy. Trends Food Sci Technol 10:393-399

Maze A, Boel G, Zuniga M, Bourand A, Loux V, Yebra MJ, Monedero V, Correia K, Jacques N, Beaufils S, Poncet S, Joyet P, Milohanic E, Casaregola S, Auffray Y, PerezMartinez G, Gibrat JF, Zagorec M, Francke C, Hartke A, Deutscher J (2010) Complete genome sequence of the probiotic Lactobacillus casei strain BL23. J Bacteriol 192(10):2647-2648. doi:10.1128/00076-10

Mennigen R, Bruewer M (2009) Effect of probiotics on intestinal barrier function. Ann N Y Acad Sci 1165:183-189. doi:10.1111/1749-6632.2009.04059

Metchnikoff E (1907) The prolongation of life: optomistic studies. William Heinemann, London

Mohamadzadeh M, Pfeiler EA, Brown JB, Zadeh M, Gramarossa M, Managlia E, Bere P, Sarraj B, Khan MW, Pakanati KC, Ansari MJ, O'Flaherty S, Barrett T, Klaenhammer TR (2011) Regulation of induced colonic inflammation by Lactobacillus acidophilus deficient in lipoteichoic acid. Proc Natl Acad Sci USA 108(Suppl 1):4623-4630. doi:10. 1073/s1005066107

Morita H, Toh H, Oshima K, Murakami M, Taylor TD, Igimi S, Hattori M (2009) Complete genome sequence of the probiotic Lactobacillus rhamnosus ATCC 53103. J Bacteriol 191(24):7630-7631. doi:10.1128/01287-09

Nes IF, Bao Diep D, Sigve Havarstein L, Bente Brurberg M, Eijsink V, Holo H (1996) Biosynthesis of bacteriocins in lactic acid bacteria. Antonie Van Leeuwenhoek 70(2): 113-128

O'Connell Motherway M, Zomer A, Leahy SC, Reunanen J, Bottacini F, Claesson MJ, O’Brien F, Flynn K, Casey PG, Moreno-Munoz JA, Kearney B, Houston AM, O'Mahony C, Higgins DG, Shanahan F, Palva A, de Vos WM, Fitzgerald GF, Ventura M, O'Toole PW, van Sinderen D (2011) Functional genome analysis of Bifidobacterium breve UCC2003 reveals type IVb tight adherence (Tad) pilli as an essential and conserved host-colonization factor. Proc Natl Acad Sci USA 108(27):11217-11222. doi:10. 1073/s1105380108
O'Flaherty SJ, Klaenhammer TR (2010a) The role and potential of probiotic bacteria in the gut, and the communication between gut microflora and the gut/host. Int Dairy J 20(4):262-268

O'Flaherty SJ, Klaenhammer TR (2010b) Functional and phenotypic characterization of a protein from Lactobacillus acidophilus involved in cell morphology, stress tolerance and adherence to intestinal cells. Microbiology 156(11): 3360-3367. doi:10.1099/0.043158-0

O'Flaherty S, Klaenhammer TR (2012) Influence of exposure time on gene expression by human intestinal epithelial cells exposed to Lactobacillus acidophilus. Appl Environ Microbiol 78(14):5028-5032. doi:10.1128/00504-12

Pfeiler EA, Klaenhammer TR (2009) Role of transporter proteins in bile tolerance of Lactobacillus acidophilus. Appl Environ Microbiol 75(18):6013-6016. doi:10.1128/0049509

Pfeiler EA, Azcarate-Peril MA, Klaenhammer TR (2007) Characterization of a novel bile-inducible operon encoding a two-component regulatory system in Lactobacillus acidophilus. J Bacteriol 189(13):4624-4634. doi:10.1128/ 00337-07

Pieterse B, Leer RJ, Schuren FHJ, van der Werf MJ (2005) Unravelling the multiple effects of lactic acid stress on Lactobacillus plantarum by transcription profiling. Microbiology 151(12):3881-3894. doi:10.1099/0.28304-0

Plummer S, Weaver MA, Harris JC, Dee P, Hunter J (2004) Clostridium difficile pilot study: effects of probiotic supplementation on the incidence of $C$. difficile diarrhoea. Int Microbiol 7(1):59-62

Porter CK, Gormley R, Tribble DR, Cash BD, Riddle MS (2011) The Incidence and gastrointestinal infectious risk of functional gastrointestinal disorders in a healthy US adult population. Am J Gastroenterol 106(1):130-138. doi:10. $1038 / 2010.371$

Pot B, Ludwig W, Kersters K, Schleifer KH (1994) Taxonomy of lactic acid bacteria. In: Cocaign-Bousquet K (ed) Bacteriocins of lactic acid bacteria. Chapman and Hall, Glasgow, pp 13-90

Pridmore RD, Berger B, Desiere F, Vilanova D, Barretto C, Pittet AC, Zwahlen MC, Rouvet M, Altermann E, Barrangou R, Mollet B, Mercenier A, Klaenhammer T, Arigoni F, Schell MA (2004) The genome sequence of the probiotic intestinal bacterium Lactobacillus johnsonii NCC 533. Proc Natl Acad Sci USA 101(8):2512-2517

Pridmore RD, Pittet AC, Praplan F, Cavadini C (2008) Hydrogen peroxide production by Lactobacillus johnsonii NCC 533 and its role in anti-Salmonella activity. FEMS Microbiol Lett 283(2):210-215. doi:10.1111/1574-6968. 2008.01176

Rafter J, Bennett M, Caderni G, Clune Y, Hughes R, Karlsson PC, Klinder A, O'Riordan M, O'Sullivan GC, Pool-Zobel B, Rechkemmer G, Roller M, Rowland I, Salvadori M, Thijs H, Van Loo J, Watzl B, Collins JK (2007) Dietary synbiotics reduce cancer risk factors in polypectomized and colon cancer patients. Am J Clin Nutr 85(2):488-496

Reid G, Chan RC, Bruce AW, Costerton JW (1985) Prevention of urinary tract infection in rats with an indigenous $\mathrm{Lac}$ tobacillus casei strain. Infect Immun 49(2):320-324

Reid G, Younes JA, Van der Mei HC, Gloor GB, Knight R, Busscher HJ (2011) Microbiota restoration: natural and 
supplemented recovery of human microbial communities. Nat Rev Microbiol 9(1):27-38. doi:10.1038/2473

Rettger LF (1915) The influence of milk feeding on mortality and growth, and on the character of the intestinal flora. J Exp Med 21(4):365-388

Rettger LF, Cheplin HA (1921) A treatise on the transformation of the intestinal flora, with special reference to implantation of Bacillus acidophilus. Yale University Press, New Haven

Ringel-Kulka T, Palsson OS, Maier D, Carroll I, Galanko JA, Leyer G, Ringel Y (2011) Probiotic bacteria Lactobacillus acidophilus NCFM and Bifidobacterium lactis Bi-07 versus placebo for the symptoms of bloating in patients with functional bowel disorders: a double-blind study. J Clin Gastroenterol 45(6):518-525. doi:10.1097/0b013e31820ca4d6

Roberfroid M (2007) Prebiotics: the concept revisited. J Nutr 137(3 Suppl 2):830S-837S

Roberfroid M, Gibson GR, Hoyles L, McCartney AL, Rastall R, Rowland I, Wolvers D, Watzl B, Szajewska H, Stahl B, Guarner F, Respondek F, Whelan K, Coxam V, Davicco MJ, Leotoing L, Wittrant Y, Delzenne NM, Cani PD, Neyrinck AM, Meheust A (2010) Prebiotic effects: metabolic and health benefits. Br J Nutr 104(Suppl 2):S1-S63. doi:10.1017/S0007114510003363

Rousseaux C, Thuru X, Gelot A, Barnich N, Neut C, Dubuquoy L, Dubuquoy C, Merour E, Geboes K, Chamaillard M, Ouwehand A, Leyer G, Carcano D, Colombel JF, Ardid D, Desreumaux P (2007) Lactobacillus acidophilus modulates intestinal pain and induces opioid and cannabinoid receptors. Nat Med 13(1):35-37. doi:10.1038/1521

Ryan KA, O'Hara AM, van Pijkeren JP, Douillard FP, O'Toole PW (2009) Lactobacillus salivarius modulates cytokine induction and virulence factor gene expression in Helicobacter pylori. J Med Microbiol 58(Pt 8):996-1005. doi:10. 1099/0.009407-0

Sanders ME, in't Huis-Veld J (1999) Bringing a probioticcontaining functional food to the market: microbiological, product, regulatory and labeling issues. Antonie Van Leeuwenhoek 76(1-4):293-315

Sanders ME, Guarner F, Guerrant R, Holt PR, Quigley EM, Sartor RB, Sherman PM, Mayer EA (2013) An update on the use and investigation of probiotics in health and disease. Gut 62(5):787-796. doi:10.1136/2012-302504

Schell MA, Karmirantzou M, Snel B, Vilanova D, Berger B, Pessi G, Zwahlen MC, Desiere F, Bork P, Delley M, Pridmore RD, Arigoni F (2002) The genome sequence of Bifidobacterium longum reflects its adaptation to the human gastrointestinal tract. Proc Natl Acad Sci USA 99(22):14422-14427. doi:10.1073/s212527599

Schnell N, Entian KD, Schneider U, Gotz F, Zahner H, Kellner R, Jung G (1988) Prepeptide sequence of epidermin, a ribosomally synthesized antibiotic with four sulfide-rings. Nature 333:276-278. doi:10.1038/333276a0

Selle K, Klaenhammer TR (2013) Genomic and phenotypic evidence for probiotic influences of Lactobacillus gasseri on human health. FEMS Microbiol Rev 37(6):915-935. doi:10.1111/1574-6976.12021

Servin AL (2004) Antagonistic activities of Lactobacilli and Bifidobacteria against microbial pathogens. FEMS Microbiol Rev 28(4):405-440. doi:10.1016/2004.01. 003
Shen YH, Nahas R (2009) Complementary and alternative medicine for treatment of irritable bowel syndrome. Can Fam Physician 55(2):143-148

Shortt C (1999) The probiotic century: historical and current perspectives. Trends Food Sci Technol 10:411-417

Smits HH, Engering A, van der Kleij D, de Jong EC, Schipper K, van Capel TMM, Zaat BAJ, Yazdanbakhsh M, Wierenga EA, van Kooyk Y, Kapsenberg ML (2005) Selective probiotic bacteria induce IL-10-producing regulatory T cells in vitro by modulating dendritic cell functiont through dendritic cell-specific intercellular adhesion molecule 3-grabbing nonintegrin. J Allergy Clin Immunol 115(6): 1260-1267

St Amant DC, Valentin-Bon IE, Jerse AE (2002) Inhibition of Neisseria gonorrhoeae by Lactobacillus species that are commonly isolated from the female genital tract. Infect Immun 70(12):7169-7171

Stoeker L, Nordone S, Gunderson S, Zhang L, Kajikawa A, LaVoy A, Miller M, Klaenhammer TR, Dean GA (2011) Assessment of Lactobacillus gasseri as a candidate oral vaccine vector. Clin Vaccine Immunol 18(11):1834-1844. doi:10.1128/05277-11

Takeda K, Okumura K (2007) Effects of a fermented milk drink containing Lactobacillus casei strain Shirota on the human NK-cell activity. J Nutr 137(3 Suppl 2):791S-793S

Taranto MP, Fernandez Murga ML, Lorca G, de Valdez GF (2003) Bile salts and cholesterol induce changes in the lipid cell membrane of Lactobacillus reuteri. J Appl Microbiol 95(1):86-91. doi:10.1046/1365-2672.2003.01962

Tissier H (1900) Recherche sur la flore intestinale des nourissons (Etat normal et pathologique). PhD Thesis, Université de Médécine, Paris

Tuomola EM, Salminen SJ (1998) Adhesion of some probiotic and dairy Lactobacillus strains to Caco-2 cell cultures. Int J Food Microbiol 41(1):45-51

Turroni F, Ribbera A, Foroni E, van Sinderen D, Ventura M (2008) Human gut microbiota and bifidobacteria: from composition to functionality. Antonie Van Leeuwenhoek 94(1):35-50. doi:10.1007/s10482-008-9232-4

Turroni F, Taverniti V, Ruas-Madiedo P, Duranti S, Guglielmetti S, Lugli GA, Gioiosa L, Palanza P, Margolles A, van Sinderen D, Ventura M (2014) Bifidobacterium bifidum PRL2010 modulates the host innate immune response. Appl Environ Microbiol 80(2):730-740. doi:10.1128/ 03313-13

Ushiyama A, Tanaka K, Aiba Y, Shiba T, Takagi A, Mine T, Koga Y (2003) Lactobacillus gasseri OLL2716 as a probiotic in clarithromycin-resistant Helicobacter pylori infection. J Gastroenterol Hepatol 18(8):986-991

van Baarlen P, Troost FJ, van Hemert S, van der Meer C, de Vos WM, de Groot PJ, Hooiveld GJ, Brummer RJ, Kleerebezem M (2009) Differential NF- $\kappa B$ pathways induction by Lactobacillus plantarum in the duodenum of healthy humans correlating with immune tolerance. Proc Natl Acad Sci USA 106(7):2371-2376. doi:10.1073/0809919106

van Baarlen P, Troost F, van der Meer C, Hooiveld G, Boekschoten M, Brummer RJ, Kleerebezem M (2011) Human mucosal in vivo transcriptome responses to three Lactobacilli indicate how probiotics may modulate human cellular pathways. Proc Natl Acad Sci USA 108(Suppl 1):4562-4569. doi:10.1073/1000079107 
van de Guchte M, Penaud S, Grimaldi C, Barbe V, Bryson K, Nicolas P, Robert C, Oztas S, Mangenot S, Couloux A, Loux V, Dervyn R, Bossy R, Bolotin A, Batto JM, Walunas T, Gibrat JF, Bessieres P, Weissenbach J, Ehrlich SD, Maguin E (2006) The complete genome sequence of Lactobacillus bulgaricus reveals extensive and ongoing evolution. Proc Natl Acad Sci USA 103(24):9274-9279. doi:10.1073/0603024103

van Pijkeren JP, Canchaya C, Ryan KA, Li Y, Claesson MJ, Sheil B, Steidler L, O'Mahony L, Fitzgerald GF, van Sinderen D, O'Toole PW (2006) Comparative and functional analysis of sortase-dependent proteins in the predicted secretome of Lactobacillus salivarius UCC118. Appl Environ Microbiol 72(6):4143-4153. doi:10.1128/03023-05

Velez MP, De Keersmaecker SC, Vanderleyden J (2007) Adherence factors of Lactobacillus in the human gastrointestinal tract. FEMS Microbiol Lett 276(2):140-148. doi:10.1111/1574-6968.2007.00908

Velraeds MM, van der Mei HC, Reid G, Busscher HJ (1996) Inhibition of initial adhesion of uropathogenic Enterococcus faecalis by biosurfactants from Lactobacillus isolates. Appl Environ Microbiol 62(6):1958-1963

Ventura M, Canchaya C, Del Casale A, Dellaglio F, Neviani E, Fitzgerald GF, van Sinderen D (2006) Analysis of bifidobacterial evolution using a multilocus approach. Int J Syst Evol Microbiol 56(Pt 12):2783-2792. doi:10.1099/0.64233-0

Viljanen M, Kuitunen M, Haahtela T, Juntunen-Backman K, Korpela R, Savilahti E (2005) Probiotic effects on faecal inflammatory markers and on faecal $\operatorname{IgA}$ in food allergic atopic eczema/dermatitis syndrome infants. Pediatr Allergy Immunol 16(1):65-71. doi:10.1111/1399-3038.2005.00224
Wells JM, Mercenier A (2008) Mucosal delivery of therapeutic and prophylactic molecules using lactic acid bacteria. Nat Rev Microbiol 6(5):349-362. doi:10.1038/1840

Whitehead K, Versalovic J, Roos S, Britton RA (2008) Genomic and genetic characterization of the bile stress response of probiotic Lactobacillus reuteri ATCC 55730. Appl Environ Microbiol 74(6):1812-1819. doi:10.1128/02259-07

Wiedemann I, Breukink E, van Kraaij C, Kuipers OP, Bierbaum G, de Kruijff B, Sahl HG (2001) Specific binding of nisin to the peptidoglycan precursor lipid II combines pore formation and inhibition of cell wall biosynthesis for potent antibiotic activity. J Biol Chem 276:1772-1779. doi:10. 1074/M006770200

Zhang ZY, Liu C, Zhu YZ, Zhong Y, Zhu YQ, Zheng HJ, Zhao GP, Wang SY, Guo XK (2009) Complete genome sequence of Lactobacillus plantarum JDM1. J Bacteriol 191(15):5020-5021. doi:10.1128/00587-09

Zhou M, Theunissen D, Wels M, Siezen RJ (2010) LAB-Secretome: a genome-scale comparative analysis of the predicted extracellular and surface-associated proteins of lactic acid bacteria. BMC Genom 11:651. doi:10.1186/ 1471-2164-11-651 